\title{
Urgences
}

\section{En privilégiant...}

\section{Louise Cotnoir}

Numéro 15, octobre 1986

\section{Épigraphiques}

URI : https://id.erudit.org/iderudit/025276ar

DOI : https://doi.org/10.7202/025276ar

Aller au sommaire du numéro

\section{Éditeur(s)}

Urgences

\section{ISSN}

0226-9554 (imprimé)

1927-3924 (numérique)

Découvrir la revue

\section{Citer ce document}

Cotnoir, L. (1986). En privilégiant... Urgences, (15), 7-7.

https://doi.org/10.7202/025276ar d'utilisation que vous pouvez consulter en ligne.

https://apropos.erudit.org/fr/usagers/politique-dutilisation/ 


\section{Louise Cotnoir}

[...] dit-il avec mépris. - "Avez-vous l'intention d'être seulement personnel?"

- Je suis personnelle - et toute personne l'est, qui écrit bien.

Djuna Bames dans: The New York Tribune (16 février 1919)

En privilégiant cette "épigraphe" d'Andrew Field à la biographie de Djuna Barnes, elle choisit de renvoyer au mépris du monde, son indifférence. Une façon de répondre encore présente, avec désarroi. Par cette mise en abîme, elle cherche à ruiner l'étrangeté, l'inattendue. Souvent elle disparaît dans ce qui lui semble grave. Le prénom, Djuna, le répété de la séduction. Lentement elle se soumet à la délation. Oui. Une inconnue célèbre. Elle déplie doucement son corps à la lumière. Le bois de la nuit ou la trace d'une lésion. Elle s'achemine ainsi, par fragments, dans la cohorte des exilées. Oui. Révulsée, elle bave et crache sur les épitaphes. "Elles ne sont pas mortes, elles ne mourront jamais." Il s'agit tout au plus d'expulser le mal qui tyrannise. Elle joue à la dérision pour se consoler de la souffrance, de l'effondrement qui la guette. Elle ne renonce pas tout à fait, préférant le clin d'oeil à l'absence. Oui. Elle pense volontiers la passion quand elle s'acharne contre l'épuisement du réel. Une sorte d'exorcisme pour sortir de la tragédie. Elle invente son nom, le prénom déjà déformé. Elle ne doit rien à personne. Elle veut toute la vie, jusqu'à quatre-vingt-dix ans. Drapée d'une longue cape noire, une femme brave marche à travers la ville, la mort entre les dents. Elle rêve ainsi à sa propre apparition. 